\title{
A COMPARATIVE STUDY SHOWING EFFICACY OF PREEMPTIVE INTRAVENOUS PARACETAMOL IN REDUCING POSTOPERATIVE PAIN AND ANALGESIC REQUIREMENT IN LAPAROSCOPIC CHOLECYSTECTOMY
}

\author{
Aftab Ahmad Khan ${ }^{1}$, Shabir Ahmad Sofi2 ${ }^{2}$ Farhana Bashir³, Mushtaq Ahmad Rather ${ }^{4}$
}

\section{HOW TO CITE THIS ARTICLE:}

Aftab Ahmad Khan, Shabir Ahmad Sofi, Farhana Bashir, Mushtaq Ahmad Rather. "A Comparative Study Showing Efficacy of Preemptive Intravenous Paracetamol in Reducing Postoperative Pain and Analgesic Requirement in Laparoscopic Cholecystectomy". Journal of Evolution of Medical and Dental Sciences 2015; Vol. 4, Issue 62, August 03; Page: 10771-10777, DOI: 10.14260/jemds/2015/1555

\begin{abstract}
A double blind, prospective, randomized study was conducted on 60 patients of ASA I and II undergoing laparoscopic cholecystectomy to evaluate the efficacy of pre-emptive IV paracetamol $[\mathrm{PCM}]$ in reducing postoperative pain and analgesic requirement. Patients were randomly assigned in two groups, group A and group B of which group A received pre-emptive IV PCM 10 minutes before skin incision. It was observed that time to first analgesic required was significantly longer in group A as compared to group B and group A had significantly lower total analgesic consumption and visual analogue scores (VAS) as compared to group B. We concluded that pre-emptive use of IV PCM (Paracetamol) in laparoscopic cholecystectomy significantly decreases postoperative pain and analgesic requirement.
\end{abstract}

KEYWORDS: IV PCM, postoperative pain and analgesia, laparoscopic cholecystectomy, tramadol.

INTRODUTION: Pain is a protective mechanism designed to alert the body to potentially injurious stimulus. Postoperative pain can affect virtually all organ systems like respiratory, cardiovascular, gastrointestinal, urinary systems etc. and above all it leads to anxiety and fatigue. Surveys indicate that approximately $86 \%$ of patients experience moderate to severe pain postoperatively. ${ }^{1}$

Pre-emptive pain control is an issue dealt with in recent years. The purpose of pre-emptive analgesia is to prevent central sensitization of pain pathways that reduces the amount of analgesic requirements. ${ }^{2}$ This results in decline in morbidity promoting wellness and shortening the length of hospital stays.

Laparoscopic cholecystectomy is one of the surgical procedures being considered as a day care surgical case. Pain after laparoscopy is multifactorial and different treatments have been proposed to provide pain relief. 3,4

PCM is a mild non-opioid analgesic that is well tolerated and relatively free of side effects at clinical doses. ${ }^{5}$ It primarily acts on central nervous system by way of central cyclooxygenase inhibition, and probably has an indirect influence on the serotoninergic system. ${ }^{6}$

Present study was undertaken to find out the analgesic efficacy of pre-emptive IV PCM in decreasing postoperative pain and analgesic requirement in patients undergoing laparoscopic cholecystectomy.

MATERIAL AND METHODS: This prospective, randomized, double blind study was conducted in the department of anesthesiology and critical care GMC Srinagar from $1^{\text {st }}$ March 2015 to $31^{\text {st }}$ May 2015 after institutional ethical committee clearance. We had taken 60 patients of ASA I and II of both sexes in the age group of 20-60 years scheduled for laparoscopic cholecystectomy. 


\section{ORIGINAL ARTICLE}

Exclusion Criteria were: Patients with history of:

1. Allergic reaction to NSAIDS.

2. Bleeding diathesis.

3. Chronic alcoholism.

4. Intake of PCM for 3 months or more.

5. Cardiovascular illness.

6. Gastric or duodenal ulcer.

7. Patients converted to open cholecystectomy.

Patients were randomly allocated into two groups, group A and group B. Group A received pre-emptive IV PCM 1gram/100ml 10mts before incision. Group B received IV PCM 1gram/100ml at the end of surgery. On the evening before surgery, patients were clinically evaluated, investigated and assured. Patients were instructed about the evaluation of pain using VAS of $0-10 \mathrm{~cm}(0$-no pain and 10-worst pain).

The anesthesia technique was standardized. Anesthesia was induced with injection propofol $2 \mathrm{mg} / \mathrm{kg}$ body wt. and injection fentanyl $1 \mu \mathrm{g} / \mathrm{kgwt}$. Patients were intubated using muscle relaxant injection atracurium $0.5 \mathrm{mg} / \mathrm{kgwt}$. Anesthesia was maintained with isoflurane $(1.2 \%)$ in $50 \%$ nitrous oxide with oxygen. Patients were monitored throughout the procedure using minimum mandatory monitoring.

Postoperatively patients were monitored for pain, if the patients experienced pain injection tramadol $2 \mathrm{mg} / \mathrm{ml} \mathrm{IV}$ was given as a rescue analgesic. VAS at different time interval (15mts, 30mts, $1 \mathrm{hr}, 2 \mathrm{hr}, 4 \mathrm{hr}, 6 \mathrm{hr}, 8 \mathrm{hr}, 12 \mathrm{hr}$ and $18 \mathrm{hr}$ ) for each patient were statistically analyzed. Total rescue tramadol required/24hr by each patient was recorded.

STATISTICAL ANALYSIS: Statistical software SPSS (version 20.0) was used to carry out the statistical analysis of data. Data was analyzed by means of descriptive statistics viz, means, standard deviations and percentages and presented by means of Bar and Line diagrams. For parametric data, Student's independent t-test was employed. Chi-square test or Fisher's exact test, whichever appropriate, was used for non-parametric data. A P-value of less than 0.05 was considered statistically significant.

\section{RESULTS:}

\begin{tabular}{|c|c|c|c|}
\hline Variable & $\begin{array}{c}\text { Group A } \\
\text { (n=30) }\end{array}$ & $\begin{array}{c}\text { Group B } \\
\text { (n=30) }\end{array}$ & P-value \\
\hline Age (years) & $41.5 \pm 8.72$ & $39.7 \pm 9.23$ & $0.441^{\#}$ \\
\hline Weight (Kg) & $64.3 \pm 11.12$ & $61.8 \pm 10.26$ & $0.369^{\#}$ \\
\hline Gender (M/F) & $(8 / 22)$ & $(7 / 23)$ & $0.766^{\#}$ \\
\hline ASA (I/II) & $(26 / 4)$ & $(23 / 7)$ & $0.504^{\#}$ \\
\hline \multicolumn{4}{|c}{ Table 1: Demographic profile of patients }
\end{tabular}

\# Statistically Non-significant Difference. 


\section{ORIGINAL ARTICLE}

\begin{tabular}{|c|c|c|c|c|c|}
\hline \multirow{2}{*}{ VAS At } & \multicolumn{2}{|c|}{ Group A } & \multicolumn{2}{c|}{ Group B } & \multirow{2}{*}{ P-value } \\
\cline { 2 - 5 } & Mean & SD & Mean & SD & \\
\hline 15 Min & 3.1 & 1.64 & 3.3 & 1.82 & $0.656^{\#}$ \\
\hline 30 Min & 3.0 & 1.52 & 3.9 & 1.25 & $0.015^{*}$ \\
\hline 1 Hour & 2.9 & 1.39 & 4.1 & 1.26 & $<0.001^{*}$ \\
\hline 2 Hour & 3.6 & 1.42 & 3.7 & 1.53 & $0.794^{\#}$ \\
\hline 4 Hour & 3.2 & 1.16 & 3.3 & 1.38 & $0.762^{\#}$ \\
\hline 6 Hour & 2.6 & 1.50 & 2.9 & 1.19 & $0.394^{\#}$ \\
\hline 8 Hour & 2.4 & 1.09 & 2.5 & 1.44 & $0.762^{\#}$ \\
\hline 12 Hour & 1.5 & 1.47 & 1.8 & 1.27 & $0.401^{\#}$ \\
\hline 18 Hour & 0.9 & 0.87 & 1.2 & 0.92 & $0.199^{\#}$ \\
\hline 24 Hour & 0.6 & 0.95 & 0.8 & 0.80 & $0.381^{\#}$ \\
\hline
\end{tabular}

Table 2: Comparison of VAS between two groups at various time intervals

* Statistically Significant Difference, \#Statistically Non-significant Difference.

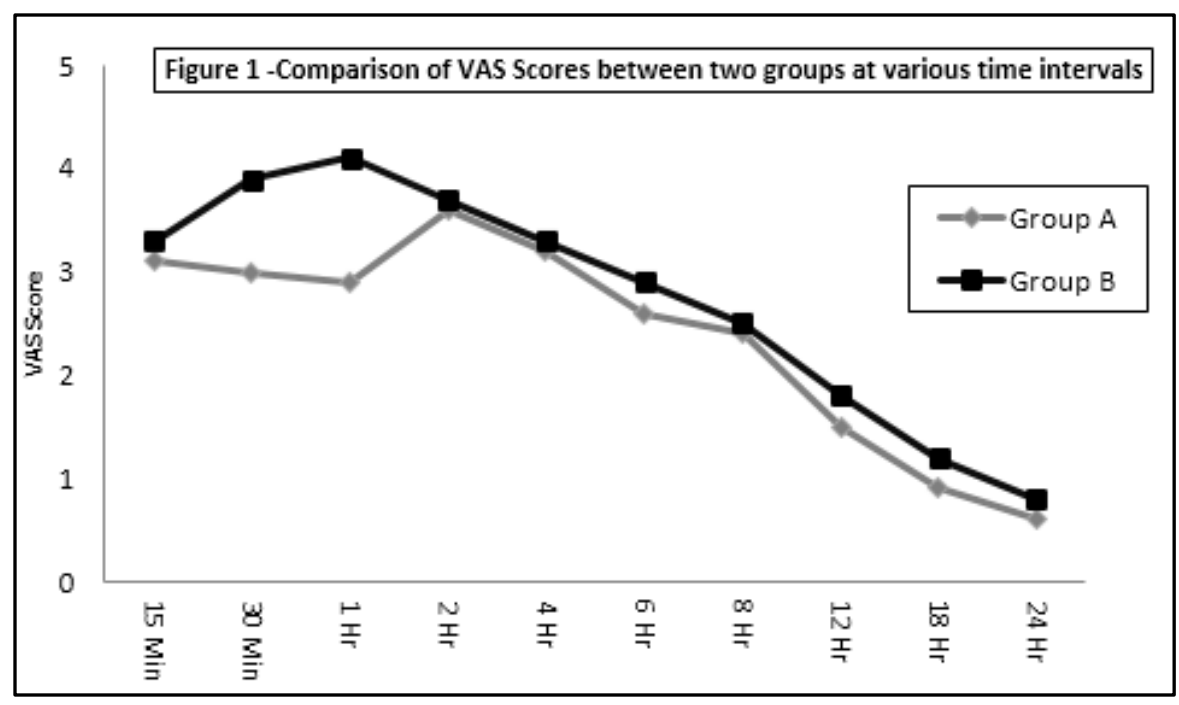

\begin{tabular}{|c|c|c|c|}
\hline & $\begin{array}{c}\text { Group A } \\
(\mathbf{n = 3 0 )}\end{array}$ & $\begin{array}{c}\text { Group B } \\
(\mathbf{n = 3 0 )}\end{array}$ & P-value \\
\hline $\begin{array}{c}\text { Analgesic Consumption } \\
\text { (tramadol mg) }\end{array}$ & $58.0 \pm 37.96$ & $106.5 \pm 45.29$ & $<0.001^{*}$ \\
\hline $\begin{array}{c}\text { Patients requiring supplemental analgesic } \\
\text { in first 6 hours, n (\%) }\end{array}$ & $13(43.3 \%)$ & $22(73.3 \%)$ & $0.018^{*}$ \\
\hline $\begin{array}{c}\text { Patients requiring supplemental } \\
\text { analgesic in 6-12 hours }\end{array}$ & $4(13.3 \%)$ & $12(40 \%)$ & $0.041^{*}$ \\
\hline $\begin{array}{c}\text { Patients requiring supplemental } \\
\text { analgesic in 12-24 hours }\end{array}$ & $0(0 \%)$ & $1(3.3 \%)$ & $1.000^{\#}$ \\
\hline \multicolumn{2}{|c|}{ Table 3: Shows analgesic consumption of patients } \\
\hline
\end{tabular}




\section{ORIGINAL ARTICLE}

* Statistically Significant Difference, \#Statistically Non-significant Difference.

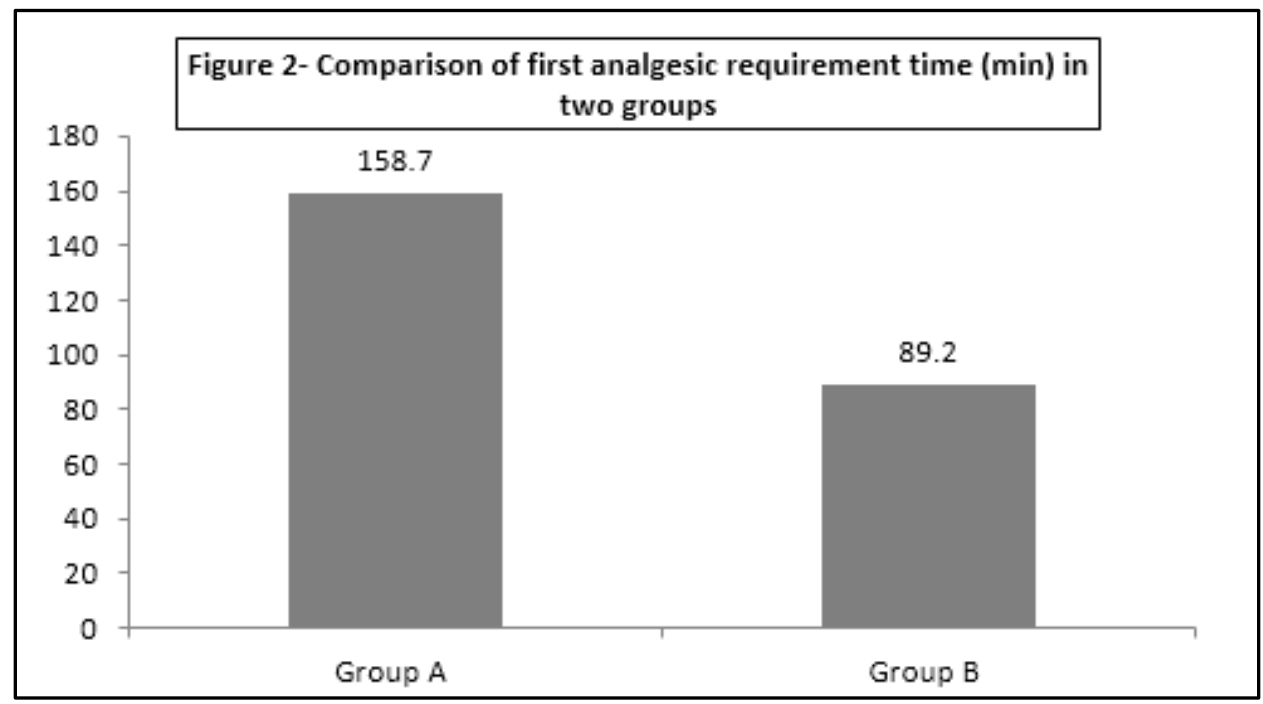

\begin{tabular}{|c|c|c|c|}
\hline & $\begin{array}{c}\text { Group A } \\
(\mathbf{n = 3 0 )}\end{array}$ & $\begin{array}{c}\text { Group B } \\
(\mathbf{n = 3 0 )}\end{array}$ & P-value \\
\hline $\begin{array}{c}\text { First Analgesic requirement } \\
\text { time (min) }\end{array}$ & $158.7 \pm 69.43$ & $89.2 \pm 43.84$ & $<0.001^{*}$ \\
\hline \multicolumn{2}{|c|}{ Table 4: Shows First Analgesic requirement time (min) }
\end{tabular}

* Statistically Significant Difference.

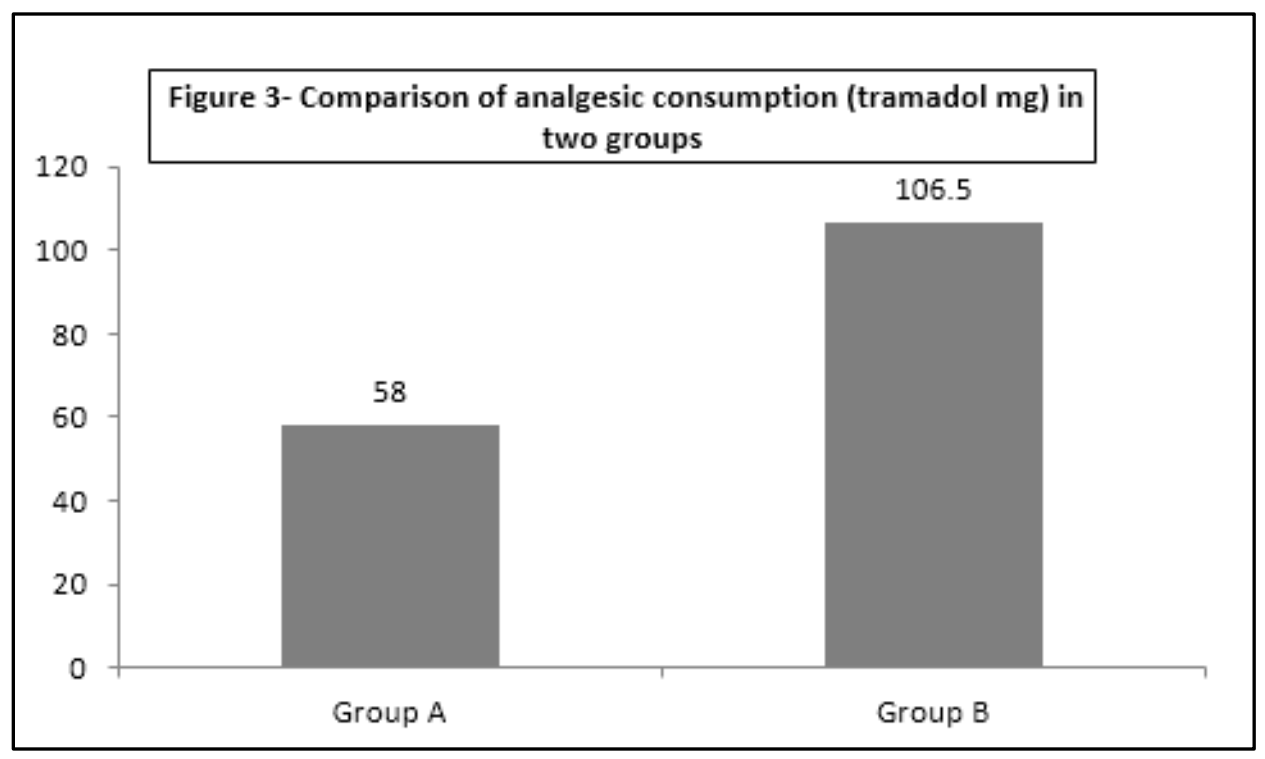

Our results showed no demographic difference among the two groups [table 1]. Patients in group A had significantly lower VAS scores as compared to group B [table 2]. The total tramadol consumption in postoperative period was $58.0 \pm 37.96$ in group A as compared to group B 


\section{ORIGINAL ARTICLE}

$106.5 \pm 45.29$ [table 3] i.e. statistically significant. Time to first analgesic requirement was significantly longer in group A $158.7 \pm 69.43$ than group B i.e. $89.2 \pm 43.84 \mathrm{mts}$ [Table 4 ].

DISCUSSION: Effective analgesia is an essential part of postoperative management and carries benefits other than increased patient comfort. Due to the negative effects and complications caused by postoperative pain, it has to be treated in a fast and effective manner. Pain management should be started prior to pain initiation. The methods and agents for which pre-emptive analgesic effectiveness has been researched are mostly NSAIDS, opioids, ketamine, PCM, peripheral local anaesthetics and epidural analgesia. ${ }^{7}$

PCM is part of the class of drugs known as 'analine analgesics'. It is the only such drug still in use today. ${ }^{8}$ It has got both central and peripheral actions. The central action is the inhibition of cyclooxygenase enzyme and recently suggested that it is highly selective for COX-2 ${ }^{8}$ and COX-3.9 ${ }^{9}$ The peripheral analgesic mechanism of PCM is due to its metabolites i.e. NAPQI (N-acetyl-p-benzoquinone imine) which acts on transient receptor potential ankyrin (TRAPAI) receptors in spinal cord to alleviate pain. ${ }^{10}$ PCM has a good safety profile and easily passes through blood brain barrier, which assures it as an effective analgesic. ${ }^{11}$

Present study demonstrates the role of pre-emptive IV PCM in reducing postoperative pain and tramadol consumption following laparoscopic cholecystectomy. IV PCM 1gram has analgesic activity in moderate to severe postoperative pain similar to ketorolac $30 \mathrm{mg}^{12}$ diclofenac $75 \mathrm{mg}^{13}$ and morphine 10mg.14 It has been observed that iv PCM 1gram preoperatively or intraoperatively provided good postoperative analgesia, with decreased requirement of morphine and reduced side effects. ${ }^{6}$

Mustafa Arsian et al [2013] in their prospective randomized study also demonstrated that IV PCM given as pre-emptive analgesic in laparoscopic cholecystectomy significantly decreases VAS scores and total opioid consumption postoperatively. ${ }^{15}$

The opioid sparing effect and decrease in postoperative pain was also observed in a study conducted by Joaquin et al [2001] using proparacetamol 2gram IV as an adjunct to PCA morphine in patients operated for spinal fusion. ${ }^{16}$

Our study is in accordance with above studies in terms of opioid sparing and reduction of postoperative VAS scores in patients undergoing laparoscopic cholecystectomy. Group A had total tramadol consumption of $58.0 \pm 37.96$ in $24 \mathrm{hrs}$ postoperatively as compared to $106.5 \pm 45.29$ in group B. The time to first analgesic requirement was $158.7 \pm 69.43$ as compared to $89.2 \pm 43.84$ in group B. Also the postoperative VAS scores were significantly decreased in group A as compared to in group B [Table 2].

Hence it can be concluded from our study that administration of preemptive IV PCM 1gram $10 \mathrm{mts}$ before surgery significantly decreases postoperative pain and total analgesic requirements and hence can be confidently used for better postoperative pain management.

\section{REFERENCES:}

1. Mesoli, Govegoankar; Post-operative pain relief for ambulatory surgery. Indian Medical Gazette April 2003: pages 138-150.

2. Grape $S$, Tramèr MR. Do we need preemptive analgesia for the treatment of postoperative pain? Best Pract Res Clin Anaesthesiol. 2007; 21: 51-63.

3. Alexander JI. Pain after laparoscopy. Br J Anaesth 1997; 79: 369. 


\section{ORIGINAL ARTICLE}

4. Wils VL, Hunt DR. Pain after laparoscopic cholecystectomy. Br J Surg 2000; 87: 273.

5. Schug SA, Sidebotham DA, McGuinnety M, Thomas J, Fox L. Acetaminophen as an adjunct to morphine by patient-controlled analgesia in the management of acute postoperative pain. Anesth Analg. 1998 Aug; 87(2): 368-72.

6. Semih Arici, Alp Gurbet et al. Pre-emptive analgesic effects of intravenous paracetamol in total abdominal hysterectomy. Agri 2009; 21(2): 54-61.

7. Woolf CJ, Chong MS. Preemptive analgesia--treating postoperative pain by preventing the establishment of central sensitization. Anesth Analg 1993; 77: 362-79.

8. Bertolini A, Ferrari A, Ottani A, Guerzoni S, Tacchi R, Leone S. "Paracetamol: new vistas of an old drug". CNS Drug Reviews 2006; 12 (3-4): 250-75.

9. Chandrashekaran NV et al. PNAS Oct. 15, 2000, Vol. 99, No. 21: 13926-13931.

10. Anderson DA, Gentry C, Alenmyr L, Killander D, Lewis SE et al. TRPAI mediates spinal antinociception induced by acetaminophen and the cannabinoid 9-tetrahydrocannabiorcol. Nat Commun 2011; 2: 551.

11. Flouvat B, Leneveu A, Fitoussi S, Delhotal-Landes B, Gendron A. Bioequivalence study comparing a new paracetamol solution for injection and propacetamol after single intravenous infusion in healthy subjects. Int J Clin Pharmacol Ther 2004; 42: 50-7.

12. Lee SY, Lee WH, Lee EH, Han KC, Ko YK. He effects of paracetamol, ketorolac, and paracetamol plus morphine on paincontrol after thyroidectomy. Korean J Pain. 2010; 23: 124-30.

13. Akarsu S, Sahin S, Kara C, Akdemir N, Degerli S. A comparison between parenteral paracetamol and diclofenac for acute postoperetive pain treatment in patients after caeserean section. J Turk Soc Obstet Gynecol. 2010; 7: 262-6.

14. Craig M, Jevons R, Probert J, Benger J. Randomised comparison of intravenous paracetamol and intravenous morphine for acute traumaticlimb pain in the emergency department. Emerg Med J. 2012; 29: 37-9.

15. Mustafa Arslan, Bahadır Celep, Ramazan Çiçek, Hülya Üstün Kalender, and Hüseyin Yılmaz. Comparing the efficacy of preemptive intravenous paracetamol on the reducing effect of opioid usage in cholecystectomy. J Res Med Sci. 2013 Mar; 18(3): 172-177.

16. Hernandez-Palazon J, Tortosa JA, Martinez-Lage JF, Perez-Flores D. Intravenous administration of propacetamol reduces morphine consumption after spinal fusion surgery. Anesth Analg. 2001 Jun; 92(6): 1473-6. 


\section{ORIGINAL ARTICLE}

\section{AUTHORS:}

1. Aftab Ahmad Khan

2. Shabir Ahmad Sofi

3. Farhana Bashir

4. Mushtaq Ahmad Rather

\section{PARTICULARS OF CONTRIBUTORS:}

1. Associate Professor, Department of Anaesthesiology and Critical Care, GMC Srinagar.

2. Senior Resident, Department of Anaesthesiology and Critical Care, GMC Srinagar.

3. Senior Resident, Department of Anaesthesiology and Critical Care, GMC Srinagar.

FINANCIAL OR OTHER

COMPETING INTERESTS: None
4. Senior Resident, Department of Anaesthesiology and Critical Care. GMC Srinagar.

\section{NAME ADDRESS EMAIL ID OF THE} CORRESPONDING AUTHOR:

Mushtaq Ahmad Rather.

Senior Resident,

Department of Anaesthesiology and

Critical Care, GMC, Srinagar-190006.

E-mail: mushtaqahmad767@gmail.com

Date of Submission: 13/07/2015.

Date of Peer Review: 14/07/2015.

Date of Acceptance: 27/07/2015.

Date of Publishing: 31/07/2015. 